\title{
Exploring the Attitudes of Instructors Toward Microsoft Teams Using the Technology Acceptance Model
}

\author{
Dalal F. Al Enezi ${ }^{1}$, Anam A. Al Fadley ${ }^{1} \&$ Ebrahim G. Al Enezi ${ }^{1}$ \\ ${ }^{1}$ College of Basic Education, Public Authority of Applied Education and Training, Kuwait City, Kuwait \\ Correspondence: Anam A. Al Fadley, College of Basic Education, Public Authority of Applied Education and \\ Training, Kuwait City, Kuwait.
}

Received: August 21, 2021

doi:10.5539/ies.v15n1p123
Accepted: October 12, $2021 \quad$ Online Published: January 19, 2022

URL: https://doi.org/10.5539/ies.v15n1p123

\begin{abstract}
The research and data aim to (a) examine instructors' evaluation of Microsoft Teams as reflected in their teaching at the Public Authority for Applied Education and Training (PAAET) and (b) identify significant correlation between three determinants of the Technology Acceptance Model: perceived usefulness (PU), perceived ease of use (PEOU), and attitudes towards use (ATU). The researchers used a self-report survey answered by 230 instructors from multiple departments at the College of Basic Education. Several statistical tools examined mean differences. The research found that the instructors at PAAET highly rate Microsoft Teams. Perceived usefulness directly affected attitudes towards use while perceived ease of use (PEOU) indirectly affected attitudes towards use.
\end{abstract}

Keywords: technology acceptance model (TAM), perceived usefulness, perceived ease of use, attitudes towards use

\section{Introduction}

The rapid progress of information technologies made E-learning an integral part of the modern education system. Given the COVID-19 pandemic, educational institutions worldwide shifted to virtual learning. Educational institutions adapted to a virtual learning environment (VLE). This transition from a traditional classroom to a virtual classroom was a struggle for many countries, especially countries that lack experience with virtual education. This adjustment proved to be difficult for Kuwait.

\section{Literature Review}

\subsection{Education in Kuwait During the COVID-19 Pandemic}

On the 26th of February 2020, two days after the first local case of COVID-19 was confirmed, the Ministry of Education (MOE) announced the closure of all schools and universities in Kuwait. It was expected that schools and universities would resume after the two-week closure. However, with the increasing number of COVID-19 cases, MOE halted the 2019-2020 academic year to set up their nation-wide E-learning program.

The Public Authority for Applied Education and Training (PAAET) launched a training campaign for students and instructors in all colleges and institutes during May 2020. Prior to the pandemic, PAAET did not use virtual learning systems. Before resuming the semester, students and employees required adequate training. The training programs taught participants how to use Microsoft Teams and Moodle. The training campaign was open to teachers, faculty, and students. Many of the participants preferred Microsoft Teams over Moodle because of its user-friendly features that will be described in the next section. According to Neubauer and Lober (2003), an E-learning environment is classified in one of the following two categories: (a) distance education: completely online using web-based technologies or (b) technology-mediated learning: on-campus teaching is complemented with web-based teaching. PAAET's E-learning environment prior to the pandemic would be classified as technology-mediated learning. Prior to the pandemic, instructors had the option of integrating learning platforms, such as Moodle, into their classroom. However, many rejected the platforms as they preferred traditional modes of learning.

After training students and instructors for three months, PAAET resumed the unfinished spring semester on August $9^{\text {th }}, 2020$. Two weeks after the conclusion of the spring semester, the summer semester commenced on October $18^{\text {th }}, 2020$, and ended on November $30^{\text {th }}, 2020$. Given the second wave of COVID-19, E-learning continued 
through 2021. The 2020-2021 academic year started on December $13^{\text {th }}, 2020$, and ended on August $2^{\text {nd }}, 2021$. All throughout the academic year, we investigated instructors' perceptions of Microsoft Teams as their main platform for E-Learning.

\subsection{Microsoft Teams}

Microsoft Teams is "a cloud app digital hub that brings conversations, meetings, files and apps together in a single Learning Management System (LMS) (Microsoft, 2018). Microsoft Teams has many features that make virtual teaching and learning seamless. For example, Martin and Tap (2019) explained that downloading Microsoft 365 Suite provides a license that enables users to run Microsoft apps on up to five devices. The application works for Mac, PC, mobile, and Android users. This feature encourages teachers to engage with their students during class-hours and out-of-class hours because students can receive instant notifications regarding their homework, graded assignments, announcements, or responses to their messages (Phillips, 2018).

Tsai (2018) pinpointed that Microsoft Teams offers functionality through chat rooms, video conferencing, and features that replicate social media applications. Rojabi (2020) discussed other features such as file sharing, screen sharing, communicating in a chat box, changing the role of participants to attendees or presenters, recording web conferences, and downloading recordings. In addition, teachers can post assignments to individuals, small groups, or the class using the assignment function. Teachers can adjust assignments for everyone in their diverse classroom of learning styles and academic abilities (Allison \& Hudson, 2020; Pretorius, 2018). All these features make Microsoft Teams a successful learning platform. All its features allow for an inclusive asynchronous and synchronous educational environment. Hoe et al. (2020) explained that synchronous learning (via live sessions) is a mode of virtual learning similar to a traditional classroom. Teachers in a synchronous class meet with students virtually through video-conferencing applications. However, in an asynchronous class, teachers facilitate learning by providing resources and allowing students to work at their own pace. Additionally, Microsoft Teams' unique features allow for elderly faculty members, faculty who prefer traditional teaching practices, to feel comfortable teaching virtually. Saranya (2020) confirms this in her study, where she investigated the efficiency of basic functions in Microsoft Teams, noting ease in discussion, assessment, and user-interface features for teachers. Results stated that elderly instructors are embracing virtual teaching through Microsoft Teams.

In this paper, the researchers are investigating the PAAET instructors' satisfaction levels with Microsoft Teams in regard to three aspects: perceived ease of use, perceived usefulness, and attitudes towards use (ATU). These three components, essential to the Technology Acceptance Model (TAM), will be discussed in the next section.

\subsection{The Technology Acceptance Model (TAM)}

The Technology Acceptance Model was developed by Davis (1989) who investigated use and acceptance of information systems and technologies by individual users. Alexender et al. (2018) reviewed the historical contexts that explain the acceptance and acceptability of users. They categorized TAM as a user-centered and productivity-oriented approach. The model predicts the behaviour of use and the intention of use. The model is widely studied by researchers that examined acceptance behaviour across different information systems (Surendran, 2012). The original model is modified consistently given the abundance of studies that use the TAM (Taylor \& Todd, 1995; Chau, 1996; Agarwal \& Prasad, 1998; Lim, 2001; Van der Heijden, 2000; Chau \& Hu, 2001; Venkatesh et al., 2003; Franco \& Roldan, 2005; Lee et al., 2009).

TAM has two essential constructors: perceived usefulness (PU) and perceived ease of use (PEOU). Davis (1989) defined perceived usefulness as "The degree to which a person believes that using a particular system would enhance his or her job performance." While perceived ease of use is, "The degree to which a person believes that using a particular system would be free of effort." For Davis (1989), both constructs contribute to the acceptance or rejection of information technology since the two constructs are determinants of system use. Alexender et al. (2018) explained that PU and PEOU are cognitive independent constructs. However, PU has the strongest link to use and intention of use, the last component in TAM. In other words, PU is "About $50 \%$ more influential than PEOU." These two components are influenced by external variables such as political, cultural, and social factors (Suredran, 2012). According to Davis, Bagozzi, and Warshaw (1989), "external variables provide the bridge between the internal beliefs, attitudes and intentions represented in TAM and the various individual differences, situational constraints and managerially controllable interventions impinging on behavior." Therefore, TAM ensures the impact of external factors on the behavioral intention (BI) for technology use as mediated by PEOU and PU (Venkatesh \& Davis, 2000).

Suredran (2012) defined two other components of TAM: attitudes towards use (ATU) and behavioral intention to use (BI); attitudes towards use are concerned with the user's desirability of employing a particular information system application while behavioural intention measures the likelihood of a person employing the application 
(Suredran, 2012).

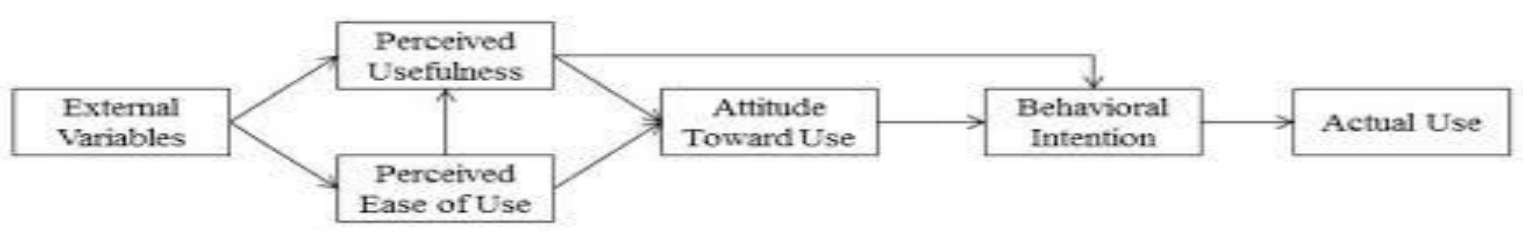

Figure 1. Technology Acceptance Model (TAM) (Davis, 1989)

Boateng et al. (2016) investigated the determinants of E-learning according to TAM and found that PU and PEOU affect the attitude of adoption thereby affecting the adoption of E-learning systems. Many researchers have applied the TAM in E-learning studies and found that perceived ease of use and perceived usefulness have significant effects on an individual's behavioral intention to use an E-learning system (Liu, Liao, \& Pratt, 2009; Ong, Lai, \& Wang, 2004; Sheng, Jue, \& Weiwei, 2008). Furthermore, Motaghian, Hassanzadeh, and Moghadam (2013) surveyed 115 university instructors to examine the theoretical model. They concluded that perceived usefulness, perceived ease of use, and system quality increase the instructor's intention to use web-based learning systems. However, perceived usefulness was the most important factor affecting their intentions and actual use of the system (Ma, Andersson, \& Streith, 2005). Their research concluded that teachers' perceived usefulness and perceived ease of use were two determinants of their technology use. However, Al-Adwan, Al-Adwan, and Swedley (2013) investigated students' acceptance of E-learning using TAM in Jordanian universities and found that PEOU significantly influenced PU and ATU. Essentially, students who found E-learning to be an easier mode of learning noted the usefulness of the system.

TAM is widely utilized across research to measure users' satisfaction levels on many information technology applications because it assesses the users' tendency to accept technology. Prioritizing the satisfaction level of instructors ensures the use of information technology applications (Cheok \& Wong, 2015; Hoe et al., 2020). In addition, Motaghian et al. (2013) explained that although instructors and students are the users of web-based learning systems, instructors play the main role in determining the success or failure of the systems. This finding is supported by Wang and Wang's (2009) theory that when instructors conduct their teaching through a web-based learning system, students are obligated to use it. Many studies find that an instructor's control of technology and frequent communication impact learning outcomes (Arbaugh, 2000; Khan, 2005; Leidner \& Jarvenpaa, 1993). Studies show that the successful implementation of educational technologies depends largely on the attitudes and acceptance of educators (Sanchez-Franco, Martínez-López, \& Martín-Velicia, 2009; Yuen \& Ma, 2008). Thus, in this study, investigating instructors' satisfaction levels towards Microsoft Teams, specifically through the constructs of TAM determines the continuity of the platform at PAAET. This will affect other educational institutions in Kuwait that want to adopt a successful E-learning platform.

\section{Significance of the Study}

This study examines Microsoft Teams' strengths and weaknesses from the perspectives of teaching faculty at the College of Basic Education, PAAET. This determines whether to continue using Microsoft Teams or switch to another learning platform. Research confirms the significant relationship between successful E-learning engagement and positive attitudes towards it (Huang \& Liaw, 2005). Yildrim (2000) explains that instructors only use technology that will fulfill their teaching needs and student learning needs. Otherwise, they will discontinue using it. One-third of the instructors at the College of Basic Education participated in this survey. Therefore, the findings of the study are generalized.

\section{Methodology}

The researchers conducted a quantitative study to evaluate Microsoft Teams with 230 instructors participating in the survey. The researchers used a self-report survey methodology with statistical tools to examine mean differences, such as, Pearson correlation, multiple regression, Cronbach's Alpha, split - half coefficient means, and ST Deviation. The study addressed the following research questions.

1) How do the instructors at the College of Basic Education evaluate Microsoft Teams for their teaching needs according to the following dimensions?

A. Quality of live classes 
B. Quality of synchronous learning

C. Procedure for evaluating student performance

D. The general experience of E-learning

2) Are there significant relationships among the four main components of TAM: attitudes towards use (ATU), external variables (EV), perceived ease of use (PEOU), and perceived usefulness (PU)?

3) Do attitudes towards use (ATU) affect perceived usefulness (PU) or perceived ease of use (PEOU)?

\subsection{Participants}

The study sample consisted of 230 instructors from the College of Basic Education. Of the 230 instructors, $17 \%$ are assistant lecturers, $28 \%$ are assistant professors, $45 \%$ are associate professors, and $10 \%$ are professors. Approximately $45 \%$ of the sample strongly agreed and $38 \%$ agreed that they received sufficient training on the use of Microsoft Teams. Therefore, $83 \%$ of the sample reported positively, claiming they received adequate training. Most instructors aimed for 2-3 training sessions.

Table 1. The Sample demographic

\begin{tabular}{|c|c|c|c|}
\hline & & $\mathrm{N}$ & $\%$ \\
\hline \multirow{19}{*}{ Department } & Special Needs Education & 16 & 7.0 \\
\hline & Science & 12 & 5.2 \\
\hline & Home Economics & 4 & 1.7 \\
\hline & Management \& Fundamentals of Education & 12 & 5.2 \\
\hline & Physical Education & 4 & 1.7 \\
\hline & Art Education & 8 & 3.5 \\
\hline & Musical Education & 16 & 7.0 \\
\hline & Interior Design & 4 & 1.7 \\
\hline & Information Technology & 8 & 3.5 \\
\hline & Islamic Studies & 8 & 3.5 \\
\hline & Social Studies & 16 & 7.0 \\
\hline & Mathematics & 4 & 1.7 \\
\hline & Psychology & 36 & 15.7 \\
\hline & Library and Information science & 4 & 1.7 \\
\hline & Law & 4 & 1.7 \\
\hline & English and French & 4 & 1.7 \\
\hline & Arabic Language & 20 & 8.7 \\
\hline & Curriculum and Methods of Teaching & 36 & 15.7 \\
\hline & Electrical Engineering & 14 & 6.1 \\
\hline \multirow{4}{*}{ Degree } & Professor & 24 & 10.4 \\
\hline & Associate Professor & 104 & 45.2 \\
\hline & Assistant Professor & 64 & 27.8 \\
\hline & Assistant Lecturer & 38 & 16.5 \\
\hline \multirow{8}{*}{ The amount of training courses I took in preparation for using Microsoft Teams } & 1 & 44 & 19.1 \\
\hline & 2 & 68 & 29.6 \\
\hline & 3 & 76 & 33.0 \\
\hline & 4 & 8 & 3.5 \\
\hline & 5 & 16 & 7.0 \\
\hline & 6 & 4 & 1.7 \\
\hline & 7 & 8 & 3.5 \\
\hline & More than 7 & 6 & 2.6 \\
\hline Total & & 230 & 100.0 \\
\hline
\end{tabular}




\subsection{Instrument and Procedures}

The original survey was written in Arabic and later translated to English. To ensure the validity of this instrument, a panel of professors from the College of Basic Education and Kuwait University reviewed the instruments and endorsed the content validity of the items. In addition, the researchers conducted a pilot study prior to the instrument's application and modified the questionnaire according to the reviewers' and instructors' feedback. The survey is scored using the five-point Likert scale. The researchers sent the questionnaire as a Microsoft Forms web link, distributed to each department in the College of Basic Education. Pearson correlation was used to calculate the relationship between the items with subdomains.

Table 2. Pearson correlation between items and dimensions degrees

\begin{tabular}{|c|c|c|c|c|c|c|c|c|c|}
\hline \multicolumn{2}{|c|}{$\begin{array}{l}\text { Quality of Live } \\
\text { Classes }\end{array}$} & \multicolumn{2}{|c|}{$\begin{array}{c}\text { Quality of Synchronous } \\
\text { Learning }\end{array}$} & \multicolumn{2}{|c|}{$\begin{array}{c}\text { Student } \\
\text { Performance }\end{array}$} & \multicolumn{2}{|c|}{$\begin{array}{c}\text { Experience with } \\
\text { Grading }\end{array}$} & \multicolumn{2}{|c|}{$\begin{array}{c}\text { General Experience of } \\
\text { E-Learning }\end{array}$} \\
\hline $\mathrm{N}$ & Correlation & $\mathrm{N}$ & Correlation & $\mathrm{N}$ & Correlation & $\mathrm{N}$ & Correlation & $\mathrm{N}$ & Correlation \\
\hline 1 & $.616^{* *}$ & 1 & $.311 * *$ & 1 & $.544 * *$ & 1 & $.857 * *$ & 1 & $.554 * *$ \\
\hline 2 & $.523 * *$ & 2 & $.238 * *$ & 2 & $.692 * *$ & 2 & $.849 * *$ & 2 & $.459 * *$ \\
\hline 3 & $.548 * *$ & 3 & $.268 * *$ & 3 & $.596 * *$ & 3 & $.882 * *$ & 3 & $.629 * *$ \\
\hline 4 & $.548 * *$ & 4 & $.367 * *$ & 4 & $.492 * *$ & 4 & $.849 * *$ & 4 & $.709 * *$ \\
\hline 5 & $.453 * *$ & 5 & $.526 * *$ & 5 & $.323 * *$ & & & 5 & $.611 * *$ \\
\hline 6 & $.564 * *$ & 6 & $.652 * *$ & 6 & $.551 * *$ & & & & \\
\hline 7 & $.612 * *$ & 7 & $.554 * *$ & 7 & $.585^{* *}$ & & & & \\
\hline 8 & $.481 * *$ & 8 & $.714 * *$ & 8 & $.536 * *$ & & & & \\
\hline 9 & $.384 * *$ & 9 & $.543 * *$ & 9 & $.642 * *$ & & & & \\
\hline 10 & $.507 * *$ & 10 & $.495 * *$ & 10 & $.386 * *$ & & & & \\
\hline 11 & $.278^{* *}$ & 11 & $.671 * *$ & & & & & & \\
\hline 12 & $.386^{* *}$ & 12 & $.619 * *$ & & & & & & \\
\hline 13 & $.448^{* *}$ & & & & & & & & \\
\hline 14 & $.268 * *$ & & & & & & & & \\
\hline 15 & $.569 * *$ & & & & & & & & \\
\hline 16 & $.669^{* *}$ & & & & & & & & \\
\hline
\end{tabular}

Correlation coefficients between the paragraphs and the overall score for each axe of the questionnaire were positive and statistically significant at a level of significance $(0.01)$, ranging between $(0.238-0.882)$. This indicates the availability of internal correlations and the validity of the questionnaire's paragraphs and subdomains.

\section{Results}

Our findings suggest that the survey was a reliable instrument. The internal consistency reliability (ICR) was calculated using Cronbach's Alpha and split-half coefficient.

Table 3. Reliability scores

\begin{tabular}{ccc}
\hline & Cronbach's Alpha & Split-Half Coefficient \\
\hline Quality of Live Classes & .758 & .827 \\
Quality of Synchronous Learning & .737 & .863 \\
Student Performance & .718 & .704 \\
Experience with Grades & .880 & .933 \\
General Experience of E-Learning & .530 & .672 \\
Total Questionnaire & .892 & .924 \\
\hline
\end{tabular}

As seen in Table 3, the Cronbach Alpha coefficient value stands at 0.892 and ranged between 0.53 and 0.88 . The stability value was found at 0.924 and ranged between 0.67 and 0.93 . This indicates the reliability and stability of the dimensions in the survey. 
Q1: How do the instructors at the College of Basic Education evaluate Microsoft Teams for their teaching needs according to the four dimensions?

The level of response according to the arithmetic mean:

- $1-1.8 \rightarrow$ very low

- $1.81-2.6 \rightarrow$ low

- $\quad 2.61-3.40 \rightarrow$ average

- $\quad 3.41-4.20 \rightarrow$ high

- $4.21-5 \rightarrow$ very high

Table 4. The means and STD of quality of live classes dimension

\begin{tabular}{|c|c|c|c|c|c|}
\hline $\mathrm{N}$ & Items & Mean & $\begin{array}{c}\text { Std. } \\
\text { Deviation }\end{array}$ & Level & Rank \\
\hline 1 & A large number of students attended live classes & 4.23 & .771 & $\begin{array}{l}\text { Very } \\
\text { high }\end{array}$ & 9 \\
\hline 2 & The procedure of taking attendance is easy & 4.23 & .954 & $\begin{array}{l}\text { Very } \\
\text { high }\end{array}$ & 10 \\
\hline 3 & $\begin{array}{l}\text { Spontaneously calling students to answer questions and discuss course content controls } \\
\text { attendance }\end{array}$ & 4.19 & .781 & High & 11 \\
\hline 4 & $\begin{array}{l}\text { Students participate during discussions in many ways, including raising their hands and } \\
\text { unmuting their microphones to speak }\end{array}$ & 4.39 & .683 & $\begin{array}{l}\text { Very } \\
\text { high }\end{array}$ & 4 \\
\hline 5 & The process of recording lectures and saving them online is easy & 4.39 & .696 & $\begin{array}{l}\text { Very } \\
\text { high }\end{array}$ & 5 \\
\hline 6 & Instructors can schedule lectures on Microsoft Teams for the entire semester & 4.54 & .651 & $\begin{array}{l}\text { Very } \\
\text { high }\end{array}$ & 1 \\
\hline 7 & The instructor can share the screen with students to display educational content & 4.41 & .876 & $\begin{array}{l}\text { Very } \\
\text { high }\end{array}$ & 3 \\
\hline 8 & The instructor can ask students to share their screens & 4.15 & .927 & High & 12 \\
\hline 9 & The instructor can easily mute all microphones when noises get distracting during lectures & 4.43 & .794 & $\begin{array}{l}\text { Very } \\
\text { high }\end{array}$ & 2 \\
\hline 10 & $\begin{array}{l}\text { The instructor can easily turn off a student's camera in the case of students accidentally } \\
\text { turning their cameras on }\end{array}$ & 4.24 & .842 & $\begin{array}{l}\text { Very } \\
\text { high }\end{array}$ & 7 \\
\hline 11 & Many students attend live classes without paying attention. & 3.71 & .969 & High & 13 \\
\hline 12 & The instructor's internet connection repeatedly disconnects during live classes. & 2.87 & 1.011 & Average & 15 \\
\hline 13 & The students' internet connection repeatedly disconnects during live classes & 3.17 & .924 & Average & 14 \\
\hline 14 & The instructor finds difficulty in controlling student behavior during live classes & 2.37 & 1.100 & Low & 16 \\
\hline 15 & Live classes are a good alternative to traditional classes during the COVID-19 pandemic. & 4.24 & .902 & $\begin{array}{l}\text { Very } \\
\text { high }\end{array}$ & 8 \\
\hline \multirow[t]{2}{*}{16} & $\begin{array}{l}\text { The instructor will continue using live classes even after the COVID-19 pandemic. For } \\
\text { example, during unexpected weather conditions }\end{array}$ & 4.27 & .938 & $\begin{array}{l}\text { Very } \\
\text { high }\end{array}$ & 6 \\
\hline & Dimension Total Means & 3.99 & .405 & High & \\
\hline
\end{tabular}

Table 4 demonstrates instructors' evaluation of the quality of live classes. Their assessment of live classes stands at a high level, with an average of 3.99. The survey questionnaire "Instructors can schedule lectures on Microsoft Teams for the entire semester" scored the highest approval. The survey questionnaire, "The instructor finds difficulty in controlling students' behavior during live classes" scored the lowest approval. The finding is favorable as it demonstrates the staff's extreme satisfaction with the learning platform. 
Table 5. The means and STD of quality of synchronous learning

\begin{tabular}{|c|c|c|c|c|c|}
\hline $\mathrm{n}$ & Items & Mean & $\begin{array}{c}\text { Std. } \\
\text { Deviation }\end{array}$ & Level & Rank \\
\hline 1 & $\begin{array}{l}\text { Instructors can post instructions and announcements in an exemplary way to attract the } \\
\text { attention of the students }\end{array}$ & 4.44 & .663 & $\begin{array}{l}\text { Very } \\
\text { high }\end{array}$ & 1 \\
\hline 2 & Students interact on posts in a satisfactory way & 4.03 & .881 & High & 2 \\
\hline 3 & $\begin{array}{l}\text { Students do not read announcements and ask questions repeatedly on private chats to the } \\
\text { instructor }\end{array}$ & 3.30 & 1.067 & Average & 6 \\
\hline 4 & $\begin{array}{l}\text { Announcements are not visible because students frequently post questions on the } \\
\text { dashboard }\end{array}$ & 3.16 & .949 & Average & 8 \\
\hline 5 & $\begin{array}{l}\text { A private channel was added for student questions, so the instructor's important } \\
\text { announcements remain visible for students in the general channel }\end{array}$ & 3.70 & 1.198 & High & 4 \\
\hline 6 & The instructor placed a virtual chat room for students & 3.43 & 1.138 & High & 5 \\
\hline 7 & The instructor used the Insights app to keep up with students' activities & 3.28 & 1.251 & Average & 7 \\
\hline 8 & $\begin{array}{l}\text { Students were distributed into small groups through channels in order to easily answer } \\
\text { their questions }\end{array}$ & 3.16 & 1.182 & Average & 9 \\
\hline 9 & $\begin{array}{l}\text { The instructor provided students with many links and files that contain educational content } \\
\text { through posts and files }\end{array}$ & 3.87 & .958 & High & 3 \\
\hline 10 & The application, OneNote, was used to provide written content to students & 2.65 & 1.066 & Average & 10 \\
\hline \multirow[t]{2}{*}{11} & The application, MindMeister, was used to create maps and diagrams & 2.53 & 1.043 & Low & 11 \\
\hline & Dimension Total Means & 3.35 & .529 & Average & \\
\hline
\end{tabular}

The values in Table 5 indicate the instructors' evaluation of the quality of synchronous learning. The instructors evaluated Microsoft Team's posting features averagely, with a value of 3.35. The survey questionnaire "Instructions and announcements can be posted to the students in an exemplary way to attract the attention of the students" scored the highest with an average of 4.44. Meanwhile, the questionnaires "Students were distributed into small groups through channels in order to easily answer their questions" and "The application, MindMeister, was used to create maps and diagrams" scored the lowest as they involved integration of third-party apps and other features.

Table 6. The means and STD of student performance

\begin{tabular}{|c|c|c|c|c|c|}
\hline $\mathrm{n}$ & Items & Mean & $\begin{array}{c}\text { Std. } \\
\text { Deviation }\end{array}$ & Level & rank \\
\hline 1 & The instructor used assignments and homework to evaluate students & 4.36 & .795 & $\begin{array}{l}\text { Very } \\
\text { high }\end{array}$ & 1 \\
\hline 2 & The instructor assigned projects to students to prevent cheating and copying & 3.91 & 1.070 & High & 6 \\
\hline 3 & The instructor used PowerPoint Presentations to evaluate students & 4.06 & 1.076 & High & 5 \\
\hline 4 & The instructor gave short quizzes to students after every lecture & 3.38 & 1.020 & Average & 8 \\
\hline 5 & The instructor asked oral questions to students every lecture & 4.17 & .918 & High & 2 \\
\hline 6 & $\begin{array}{l}\text { The instructor used timed tests to prevent cheating and the exchange of answers among } \\
\text { students }\end{array}$ & 3.50 & 1.350 & High & 7 \\
\hline 7 & The instructor created tests that depend on critical thinking and reasoning skills & 4.10 & 1.032 & High & 3 \\
\hline 8 & The instructor used open-book tests to evaluate students & 3.09 & 1.332 & Average & 9 \\
\hline 9 & The instructor used Microsoft Forms as a testing application for students & 4.10 & 1.121 & High & 4 \\
\hline \multirow[t]{2}{*}{10} & The instructor used Moodle as a testing platform for students & 2.22 & 1.151 & Low & 10 \\
\hline & Dimension Total Means & 3.69 & .584 & High & \\
\hline
\end{tabular}

As seen in Table 6, the instructors highly rate the mechanisms of evaluating students with a value of 3.69. Instructors at the College of Basic Education regularly use several evaluation methods, such as, projects, presentations, and short quizzes with critical thinking to prevent cheating, copying, and the exchange of answers. 
Table 7. The means and STD of experience with grades

\begin{tabular}{clcccc}
\hline $\mathrm{n}$ & \multicolumn{1}{c}{ Items } & Mean & Std. Deviation & Level & rank \\
\hline 1 & Students can easily and quickly submit homework and assignments & 4.21 & .930 & Very high & 4 \\
2 & The instructor can easily evaluate students and provide grades & 4.26 & .887 & Very high & 3 \\
3 & The instructor can easily grade tests and assign grades & 4.35 & .804 & Very high & 1 \\
4 & The instructor can easily post scores and distribute grades & 4.27 & .797 & Very high & 2 \\
& Dimension Total Means & 4.27 & .734 & Very high \\
\hline
\end{tabular}

Table 7 demonstrates the instructors' evaluation of experience with grading, rating the mechanism very highly with a value of 4.27. The "assignments and grades" feature in Microsoft Teams allows for instructors to assign tasks and projects to students as well as provide a place to submit a student's grade and assignment feedback. These features facilitate a smooth grading process.

Table 8. The means and STD of the general experience of e-learning

\begin{tabular}{|c|c|c|c|c|c|}
\hline $\mathrm{n}$ & Items & Mean & $\begin{array}{c}\text { Std. } \\
\text { Deviation }\end{array}$ & Level & rank \\
\hline 1 & Microsoft Teams is a safe environment for learning without cyber breaches & 3.92 & .827 & High & 2 \\
\hline 2 & The process of E-learning was good, with no problems to be reported & 3.85 & .918 & High & 3 \\
\hline 3 & E-learning ensures the survival of education during rough and unexpected changes & 4.35 & .782 & $\begin{array}{l}\text { Very } \\
\text { high }\end{array}$ & 1 \\
\hline 4 & E-learning is tiring and requires a lot of energy & 3.32 & 1.251 & Average & 5 \\
\hline \multirow[t]{2}{*}{5} & $\begin{array}{l}\text { The instructor is disturbed from the abundance of questions and messages from students } \\
\text { that need to be answered }\end{array}$ & 3.22 & 1.231 & Average & 4 \\
\hline & Dimension Total Means & 3.73 & .602 & High & \\
\hline
\end{tabular}

Table 8 indicates that the instructors highly rate their general experience of E-learning, with a value of 3.73. They strongly praise Microsoft Teams' ability to endure during unexpected changes. Issues with the platform are minimal at the College of Basic Education, PAAET.

Table 9. The means and STD of the dimension of questionnaire

\begin{tabular}{ccccc}
\hline Dimensions & Mean & Std. Deviation & Level & Rank \\
\hline Quality of Live Classes & 3.99 & .405 & High & 2 \\
Quality of Synchronous Learning & 3.35 & .529 & Average & 5 \\
Student Performance & 3.69 & .584 & High & 4 \\
Experience with Grades & 4.27 & .734 & Very high & 1 \\
General Experience with E-Learning & 3.73 & .602 & High & 3 \\
Total Questionnaire & 3.81 & .431 & High & \\
\hline
\end{tabular}




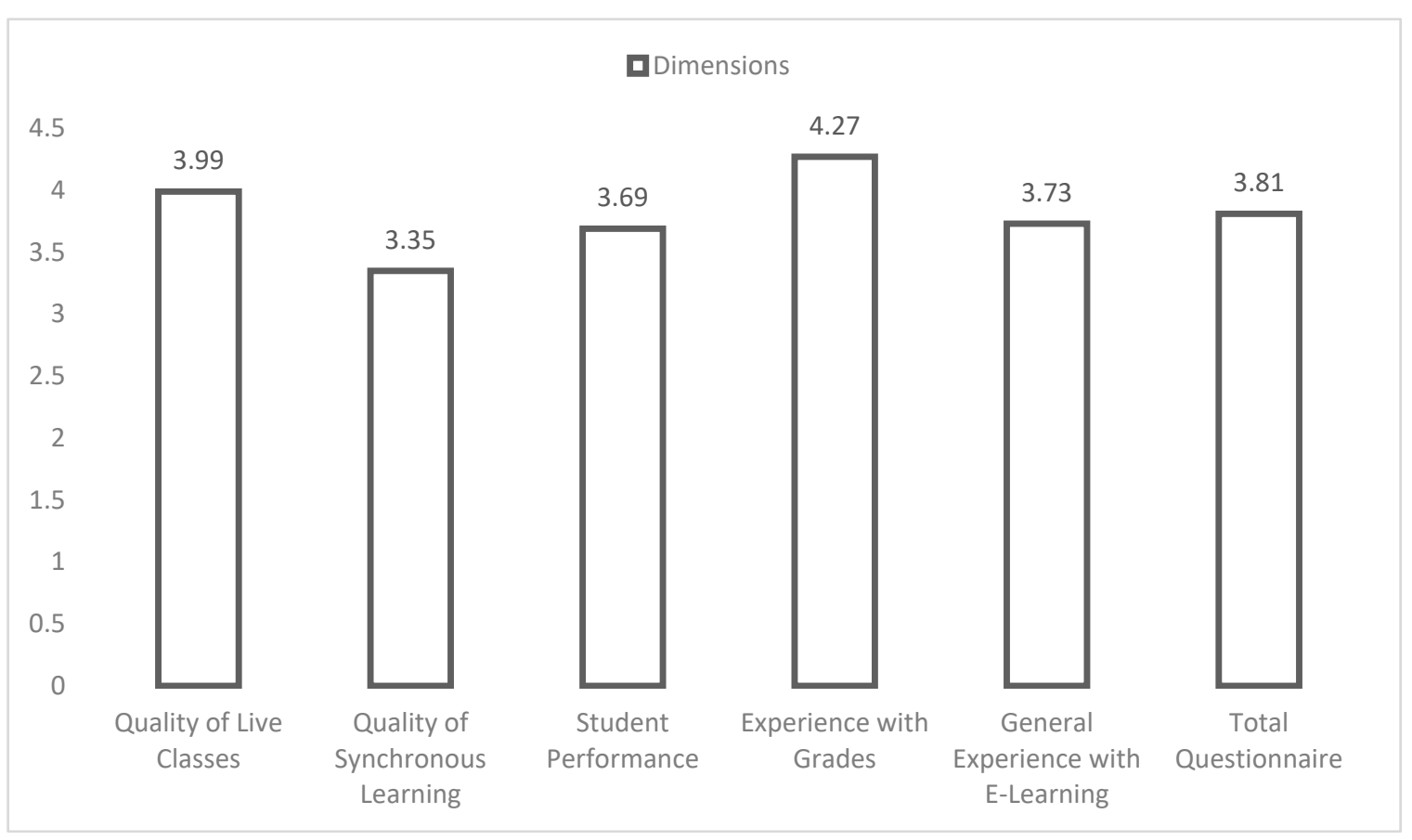

Figure 2. Bar chart of dimensions

The values in Table 9 indicate that the instructors highly evaluate the features found in Microsoft Teams, with a value of 3.81. Microsoft Teams has several highlighting properties for the instructors at the College of Basic Education, PAAET:

1) Ease in posting assignments, scores, and grades.

2) High quality of live classes with full control during broadcast.

3) High quality of synchronous learning.

Q2. Are there significant relationships among the four main components of TAM: attitudes towards use (ATU), external variables (EV), perceived ease of use (PEOU), and perceived usefulness (PU)?

In order to investigate the relationships among the factors of TAM and their effects on each other, the researchers divided the tool to the four main components:

1) External variables (EV)

2) Perceived Ease of Use (PEOU)

3) Perceived Usefulness (PU)

4) Attitudes Towards Using (ATU)

Table 10. The correlation of PU and PEOU on other TAM factors

\begin{tabular}{cccc}
\hline & External Variables (EV) & Perceived Ease of Use (PEOU) & Perceived Usefulness (PU) \\
\hline External variables (EV) & & & \\
Perceived Ease of use (PEOU) & $0.224^{* *}$ & & \\
Perceived Usefulness (PU) & $0.389^{* *}$ & $0.755^{* *}$ & \\
\hline
\end{tabular}

Note. ${ }^{* *}$ Correlation is significant at the 0.01 level.

Pearson correlation was used to describe the strength of relationship between the factors of TAM.

As can be seen from Table 10:

- There is a significant positive correlation between external variables and perceived ease of use $(r=0.224)$

- There is a significant positive correlation between external variables and usefulness $(r=0.389)$ 
- There is a significant positive correlation between perceived ease of use and usefulness $(\mathrm{r}=0.755)$

Q3. Do attitudes towards use (ATU) affect perceived usefulness (PU) or perceived ease of use (PEOU)?

In order to measure the effect of perceived ease of use (PEOU) and perceived usefulness (PU) on attitude towards using Microsoft Teams (ATU), multiple regressions was used. The independent variables are perceived ease of use (PEOU) and perceived usefulness (PU) while attitude towards using Microsoft Teams (ATU) is a dependent variable.

Table 11. The effects of (PU) and (PEOU) on (ATU)

\begin{tabular}{|c|c|c|c|c|c|}
\hline \multirow{2}{*}{ Model } & \multicolumn{2}{|c|}{ Unstandardized Coefficients } & \multirow{2}{*}{$\begin{array}{c}\text { Standardized Coefficients } \\
\text { Beta } \\
\end{array}$} & \multirow{2}{*}{$\mathrm{T}$} & \multirow{2}{*}{ Sig. } \\
\hline & $\mathrm{B}$ & Std. Error & & & \\
\hline (Constant) & .920 & .293 & & 3.139 & .002 \\
\hline Perceived Ease of Use (PEOU) & .207 & .105 & .164 & 1.966 & .051 \\
\hline Perceived Usefulness (PU) & .580 & .111 & .435 & 5.206 & .001 \\
\hline
\end{tabular}

a. Dependent Variable: Attitude Towards Using Microsoft Teams (ATU); $F=53.95^{* *} ; \mathrm{R}^{2}=0.32$.

As can be seen from Table 11:

- The effect size refers to the dependent variables affecting the variance of attitude by (32\%).

- Only perceived usefulness (PU) predicts the attitude towards using Microsoft Teams (ATU) significantly.

- The perceived ease of use (PEOU) did not predict the attitude towards using Microsoft Teams (ATU) significantly.

\section{Discussion}

The first aim of this study is to investigate the strengths and weaknesses of Microsoft Teams according to the instructors at the College of Basic Education. The results revealed that participants highly evaluate Microsoft Teams, rating the platform between average and very high for all four dimensions. The first dimension, quality of live classes, was highly rated with an average of (3.99). This indicates a strong quality of broadcasted live classes. This finding is supported by researchers that highlighted excellent features such as file sharing, screen sharing, communicating in the chat box, changing the role of participants, and recording meetings (Tsai, 2018; Rojabi, 2020). The second dimension, quality of synchronous learning, was evaluated at an average level with a value of 3.35. The survey item, "Announcements can be posted in an exemplary way to attract the attention of the students" had the highest value of 4.44. This result supports Phillips' (2018) finding that synchronous learning through Microsoft Teams encourages students to engage with their teachers during class hours and out-of-class hours as they can receive instant notifications on their mobile devices regarding homework, assignments, or class updates.

The third dimension, evaluating student performance, was evaluated with a value of 3.69. The instructors use several methods, such as, projects, presentations, and short quizzes with critical thinking questions to challenge students. This finding is supported by researchers who found that teachers can post assignments to individuals, small groups, or the class using the assignment function. They can adjust assignments for everyone in their diverse classroom of learning styles and academic abilities (Allison \& Hudson, 2020; Pretorius, 2018). The fourth dimension, experience with grades, was evaluated at a very high level, with a value of 4.27. It was the highest dimension among all four. This is likely because of the many students enrolled at the College of Basic Education, with a maximum capacity of 100 students per class. A large class causes grading to be overwhelming for instructors at the College of Basic Education. An allocated space for students to submit work and instructors to provide grades provides a seamless grading experience as opposed to grading on third-party applications. The last dimension, evaluating the general experience of E-learning, was rated at a high level with a value of 3.73. Instructors claim that Microsoft Teams provides a safe learning environment without cyber breaches, ensuring that learning survives.

The second research question investigates the relationship between three components of TAM: external variables (EV), perceived ease of use (PEOU), and perceived usefulness (PU). The results confirmed Davis' (1989) original theory as there was a positive significant relationship between external variables (EV) and perceived ease of use (PEOU), and between external variables (EV) and perceived usefulness (PU). Suredran (2012) confirmed the strong effect that external variables play on PEOU and PU. Davis' (1989) TAM demonstrated the strong relationship between the two constructs. Venkatesh and Davis expressed this relationship by stating, "The easier 
the system is to use the more useful it can be." Al-Adwan et al. (2013) also found that PEOU has a significant influence on PU.

Findings revealed that only perceived usefulness (PU) significantly predicts instructors' attitudes towards using Microsoft Teams (ATU) while the perceived ease of use (PEOU) does not predict their attitudes. Davis (1989) compared the relationships between PU and PEOU, concluding that PU was strongly correlated with technology acceptance. With PU, positive attitudes are reported, which in turn, achieves technology acceptance. This finding does not minimize the role of PU in the stages of technology acceptance given Venkatesh and Davis' (2000) finding, "The easier the system is to use the more useful it can be." This explains why no correlation exists between perceived ease of use (PEOU) and attitudes towards use (ATU). Nevertheless, Vanketesh and Davis (2000) explain that when educators enhance the ease of use (EOU), students perform better, thereby increasing their perception of usefulness which later reflect on their attitudes towards use (ATU). This result conflicts with Al-Adwan et al. (2013) because they found that PEOU has significant influence on attitudes towards using E-learning applications in Jordan. Their finding revealed that PU has no influence on the participants' attitudes towards using E-learning applications. The researchers explained that their participants' acceptance of the E-learning system relied on the application's simplicity rather than how useful it is for their learning. Hence, participants' perceived ease of use of their E-learning system affected their attitudes towards using it. In our study, PU predicted the attitudes of the instructors while PEOU did not show any correlation with their attitudes. However, Davis (1989) explained that although users might perceive learning systems to be useful, they may still find it difficult to use and thereby quit using it. Furthermore, Priyanto, Sofyan, and Surjono (2017) investigated the determinants of E-learning implementation of vocational schools in the Yogyakarta Special Region. They found that the direct determinants on perceived usefulness (PU) were perceived ease of use (PEOU) and the social environment. However, the perceived ease of use was the strongest determinant compared to the social environment. Plus, Kashada, Ghaydi, and Mohammed (2020) examined the impact of perceived usefulness (PU) and perceived ease of use (PEOU) on the successful adoption of information systems (IS) in developing countries. They found that PU directly affected the adoption of the information system while PEOU indirectly affected the adoption of the information system.

\section{Conclusion}

E-learning, while challenging, has proven to be a rewarding experience at the College of Basic Education. Many countries had to modify their educational systems by switching to virtual learning. The concern worth investigating a year into E-learning is how instructors feel about the platform, given that success or failure of any learning system stems from their evaluation. We discussed that Microsoft Teams has three highlighting properties (a) ease in posting assignments and distributing grades, (b) high quality of live classes with full control during broadcasts, and (c) high quality of synchronous learning. As for determinants of accepting Microsoft Teams, we found that perceived usefulness (PU) significantly determines instructors' attitudes towards using (ATU) Microsoft Teams. The perceived ease of use (PEOU) did not determine their attitudes. However, the study confirms the positive significant correlation between PU and PEOU. This is because PU directly affects PEOU and PEOU directly affects ATU, each factor increases the other in their respective orders. The study was generalized given that the data was obtained from one college of the five colleges at PAAET. However, more data can be obtained with the remaining departments through semi-structured interviews. This study can branch out to instructors in all departments. Future studies can examine other determinants that affect the adoption of any learning system and how to keep the learning system afloat.

\section{Acknowledgements}

I would like to thank the co-authors that contributed to this paper. I would also like to thank my research partner and editor, Sarah Qasem.

\section{References}

Al-Adwan, A., Al-Adwan, A., \& Smedley, J. (2013). Exploring students acceptance of e-learning using Technology Acceptance Model in Jordanian universities. International Journal of Education and Development using Information and Communication Technology, 9(2), 4-18.

Allison, N., \& Hudson, J. (2020, June). Integrating and sustaining directed and self-directed learning through MS Teams and OneNote: Using Microsoft Teams and OneNote to facilitate communication, assignments, and portfolio management. Presented at BALEAP TEL SIG Webinar.

Arbaugh, J. B. (2000). Virtual classroom characteristics and student satisfaction with internet-based MBA courses. Journal of Management Education, 24(1), 32-54. https://doi.org/10.1177/105256290002400104

Boateng, R., Mbrokoh, A. S., Boateng, L., Senyo, P. K., \& Ansong, E. (2016). Determinants of E-learning 
adoption among students of developing countries. International Journal of Information and Learning Technology, 33(4), 248-262. https://doi.org/10.1108/IJILT-02-2016-0008

Chau, P. Y. K. (1996). An empirical assessment of a modified technology acceptance model. Journal of Management Information Systems, 13, 185-204. https://doi.org/10.1080/07421222.1996.11518128

Cheok, M. L., \& Wong, S. L. (2015). Predictors of E-learning satisfaction in teaching and learning for school teachers: a literature review. International Journal of Instruction, 8(1), 75-90. https://doi.org/10.12973/iji.2015.816a

Davis, F. (1989). Perceived usefulness, perceived ease of use, and user acceptance of information technology. MIS Quarterly, 13, 319-340. https://doi.org/10.2307/249008

Davis, F. D., Bagozzi, R. P., \& Warshaw, P. R. (1989). User acceptance of computer technology: A comparison of two theoretical models. Management Science, 35(8), 982-1003. https://doi.org/10.1287/mnsc.35.8.982

Huang, M., \& Liaw, S. (2005). Exploring user's attitudes and intentions toward the web as a survey tool. Computers in Human Behavior, 21(5), 729-743. https://doi.org/10.1016/j.chb.2004.02.020

Kashada, A., Ghaydi, A., \& Mohamed, W. (2020). The impact of perceived usefulness \& perceived ease of use on the successful adoption of information systems in developing countries. Journal of Computer Engineering, 22(1), 45-48. https://doi.org/10.9790/0661-2201014548

Khan, B. (2005). Managing e-learning strategies: Design, delivery, implementation, and evaluation. Hershey: Information Science Publishing. https://doi.org/10.4018/978-1-59140-634-1

Lee, B., Yoon, J., \& Lee, I. (2009). Learners' acceptance of e-learning in South Korea: Theories and results. Computers \& Education, 53, 1320-1329. https://doi.org/10.1016/j.compedu.2009.06.014

Leidner, D. E., \& Jarvenpaa, S. L. (1993). The information age confronts education: Case studies on electronic classrooms. Information Systems Research, 4(1), 24-54. https://doi.org/10.1287/isre.4.1.24

Lim, C. K. (2001). Computer self-efficacy, academic self-concept, and other predictors of satisfaction and future participation of adult distance learners. The American Journal of Distance Education, 15(2), 41-51. https://doi.org/10.1111/j.1365-2729.2005.00145.x

Liu, S., Liao, H., \& Pratt, J. (2009). Impact of media richness and flow on E-learning technology acceptance. Computers \& Education, 52(3), 599-607. https://doi.org/10.1016/j.compedu.2008.11.002

Ma, W. K., Andersson, R., \& Streith, K.-O. (2005). Examining user acceptance of computer technology: An empirical study of student teachers. Journal of Computer Assisted Learning, 21, 387-395. https://doi.org/10.1111/j.1365-2729.2005.00145.x

Martin, L., \& Tapp, D. (2019). Teaching with Teams: An introduction to teaching an undergraduate law module using Microsoft Teams. Innovative Practice in Higher Education, 3(3), 85-66.

Microsoft. (2018). Welcome to Microsoft Teams. Microsoft. Retrieved from https://docs.microsoft.com/en-us/microsoftteams/teams-overview

Motaghiam, H., Hassanzadeh, A., \& Moghadam, D. (2013). Factors affecting university instructors' adoption of web-based learning systems: case study of Iran. Computer \& Education, 61, 158-167. https://doi.org/10.1016/j.compedu.2012.09.016

Neubauer, M., \& Lobel, M. (2003). The learning by doing E-classroom. Journal of the USDLA, 17(2), 5-17.

Ong, C., Lai, J., \& Wang, Y. (2004). Factors affecting engineers' acceptance of asynchronous E-learning systems in high-tech companies. Information \& Management, 41(6), 795-804. https://doi.org/10.21831/jpv.v7i1.12770

Park, S. Y. (2009). An analysis of the technology acceptance model in understanding university students. Educational Technology and Science, 12(3), 150-162.

Philips, T. (2018). Setting Assignments in Microsoft Teams for Education. Retrieved from https://www.tonyishere.co.uk/setting-assignments-in-microsoft-teams-for-education/

Pretorius, M. (2018). SharePoint and Assignments. Retrieved from https://techcommunity.microsoft.com/t5/ Microsoft-Teams-for-EMicrosoft

Priyanto, P., Sofyan, H., \& Surjono, H. D. (2017). The determinants of E-learning usage by teachers of vocational high schools in the Yogyakarta Special Region. Journal Pendidikan Vokasi, 7, 1-13. 
https://doi.org/10.21831/jpv.v7i1.12770

Ritu, A., \& Prasad, J. (1998). A conceptual and operational definition of personal innovativeness in the domain of information technology. Informs, 9(2), 101-215. https://doi.org/10.1287/isre.9.2.204

Rojabai, A. (2020). Exploring EFL students' perceptions of online learning via Microsoft Teams: University level in Indonesia. English Language Teaching Educational Journal, 3(2), 163-173. https://doi.org/10.12928/eltej.v3i2.2349

Sanchez-Franco, M. J., Martínez-López, F. J., \& Martín-Velicia, F. A. (2009). Exploring the impact of individualism and uncertainty avoidance in web-based electronic learning: an empirical analysis in European higher education. Computers \& Education, 52(3), 588-598. https://doi.org/10.1016/j.compedu.2008.11.006

Sanchez-Franco, M., \& Roldan, J. (2005). Web acceptance and usage model: A comparison between goal-directed and experiential web users. Emerald Insight, 15(1), 21-48. https://doi.org/10.1108/10662240510577059

Saranya, A. K. (2020). A critical study on the efficiency of Microsoft Teams in online education. In R. Gayathri (Ed.), Efficacy of Microsoft Teams during COVID-19 (pp. 310-323). Toronto: Bonfring Publication.

Surendran, P. (2012). Technology Acceptance Model: A survey of literature. International Journal of Business and Social Research, 2(4), 175-178. https://doi.org/10.18533/ijbsr.v2i4.161

Taylor, S., \& Todd, P. A. (1995). Assessing IT usage. MIS Quarterly, 19, 561-570. https://doi.org/10.2307/249633

Tsai, P. (2018). Business chat apps in 2018: Top players and adoption plans. Retrieved from https://community.spiceworks.com/blog/3157-business-chat-apps-in-2018-topplayers-andadoption-plans\%0 A

Venkatesh, V., \& Davis, F. D. (1996). A model of the antecedents of perceived ease of use: development and test. Decision Sciences, 27(3), 451-481. https://doi.org/10.1111/j.1540-5915.1996.tb00860.x

Wang, W., \& Wang, C. (2009). An empirical study of instructor adoption of web-based learning systems. Computers \& Education, 53(3), 761-774. https://doi.org/10.1016/j.compedu.2009.02.021

Yildrim, S. (2000). Effects of an educational computing course on pre-service and in-service teachers: A discussion and analysis of attitudes and use. Journal of Research on Computing in Education, 32(4), 479-495. https://doi.org/10.1080/08886504.2000.10782293

Yuen, A. H. K., \& Ma, W. W. K. (2008). Exploring teacher acceptance of e-learning technology. Asia-Pacific Journal of Teacher Education, 36(3), 229-243. https://doi.org/10.1080/13598660802232779

Zhang, S., \& Zhao, J. (2008). Ending TAM for online learning systems: An intrinsic motivation perspective. Tsinghua Science \& Technology, 13(3), 312-317. https://doi.org/10.1016/S1007-0214(08)70050-6

\section{Copyrights}

Copyright for this article is retained by the author(s), with first publication rights granted to the journal.

This is an open-access article distributed under the terms and conditions of the Creative Commons Attribution license (http://creativecommons.org/licenses/by/4.0/). 